\title{
Achieving Local Content in Extractive Industries of African Countries
}

\author{
${ }^{1}$ Richard A Owusu, 2 Terje I Vaaland \\ ${ }^{1}$ School of Business and Economics, Linnaeus University, SE39182 Kalmar, Sweden \\ 2 Uis Business School, University of Stavanger, N-4036, Stavanger, Norway
}

\begin{abstract}
Local content defines the extent of participation of local industry in extractive industries like mining, oil and gas. These industries are major destinations of foreign direct investments. They are very important revenue streams for governments of developing and emerging economies. In many countries, however, local industry is not participating enough. Recently researchers are bringing new perspectives into research and policy on the subject. We discuss the issue based on a review of relevant literature including a study in Nigeria in the wake of the passage of the new local content laws. Our study finds that the achievement of local content depends on the collaboration of a range of actors. Local political and legal institutions, local businesses, MNCs, universities and research organizations, international development partners and donors have to contribute their political and economic resources to achieve local content.
\end{abstract}

Keywords: Africa emerging markets, Local content, Local participation in extractive industries; Local participation in oil and gas industries.

\section{Introduction}

One of the factors that determine the extent of positive impact of natural resource extraction is the level of local content (LC) in the industry. The World Trade Organization (WTO, 2011) defines local content requirements, synonymously referred to as domestic content requirements as a "requirement that the investor purchase a certain amount of local materials for incorporation in the investor's product". The fundamental task is to "involve and enhance the domestic knowledge base through arrangements that allow for a dynamic industrial and technological development, that gradually expand domestic competence and capabilities to competitive levels" (Heum, 2008:4).

The research on LC is still in its infancy. Issues related to technology transfer and vertical integration have been studied by e.g. Kwon \& Chun (2009); backward linkages between foreign multinationals controlling natural resource extraction and local companies by e.g. Ivarsson and Alvstam (2009), as well as Giroud (2007); effects of enhanced LC on welfare by e.g. Veloso (2006), as well as Takechi \& Kiyono (2003); LC experiences in industrialized countries by e.g. Pursell (2001); LC in Brazil by Silvestre \& Dalcol (2009); and a comparison of LC in West Africa and Central Asia by Klueh, Pastor and Segura (2009). In line with the studies mentioned above, LC has been mainly studied from industrial policy and industrial organization perspectives. We find that a stronger management and behavioural perspective is needed to understand the interrelatedness between institutions, governance, local and foreign companies, their capabilities and how they impact the achievement of LC. A recent study of the LC experience within Nigeria's oil industry showed the lack of collaboration between various local actors as well as between them and the foreign oil producers to be a major problem. Management and behavioural factors explained a lot of the problems impeding the achievement of LC over a period of over 30 years (Vaaland, Soneye \& Owusu, 2012). 


\author{
Richard A Owusu, Terje I Vaaland \\ Achieving Local Content in Extractive Industries of African Countries
}

As more African countries find new deposits of oil and other minerals, researchers, policy makers, and managers need better understanding of the environment and interrelationships that should be developed to ensure the achievement of LC. The importance of LC is dawning on all players. In the endeavor to achieve successful LC, we need to better understand the enabling factors and challenges. In this paper, we discuss the enablers and challenges of achieving local content in extractive industries of developing countries based on a literature review and a study of local content in the Nigerian oil and gas industry (Vaaland et al, 2012). We are trying to answer the questions: how can increased LC be achieved in the extractive industries of developing countries? What are the enablers and challenges?

\title{
2. Literature Review
}

\subsection{Enablers and Challenges of Local Content}

There are two major actors in the LC regime in developing countries: institutions (local and foreign), and companies (local companies, and foreign MNCs who control the exploration and production of natural resources). Each of these actors contributes to the enabling environment and challenges. Local institutions include the decision makers; regulators; political authorities at both local and national levels; local universities and knowledge institutions providing research and policy guidance; NGOs and local pressure groups; as well as the laws and regulations the institutional actors create. Foreign institutions are powerful multi-lateral financiers and policymakers like the World Bank and IMF, foreign donors and home countries of multinational oil companies like the EU, United States and China. Local companies are the indigenous business partners and beneficiaries of LC. Foreign MNCs are the foreign multinationals who undertake exploration and production of oil, gas and other minerals. In the subsequent sections, we describe the enablers and challenges provided by the various actors and end with a discussion of our policy, management, and research implications.

\subsubsection{Institutional Enablers}

Local institutional enablers are governmental institutions or parastatals with direct or indirect influence on how the actors of the extractive industry operate. They include ministries responsible for national policy development, implementation, and monitoring of industrial and extractive activities in the country. National oil companies (NOCs) mediate between the central Government and oil producing MNCs. They are given implementation and policy development functions (Boscheck, 2007). The NOCs negotiate directly with the oil producing MNCs and supervise them. They also manage the national investments in the industry. They advise the Governments on the level of ownership, royalties and taxes to demand. As they work directly with the producers, their capabilities are very important in ensuring trust and fairness from the point of view of both parties. Various governmental and parastatal providers of critical infrastructure to the extraction industry like the Nigerian Electric Power Authority (NEPA) provide important capabilities. Legal institutions are also crucial for the work of the extraction companies. These include the lawmakers, the law enforcing police and prosecuting forces, and the court system necessary for providing protection, stability and a law abiding society. Other local institutions are universities and knowledge centers that develop and disseminate knowledge and technologies to political institutions, parastatals and companies. Additionally, NGOs and local pressure groups are critical in ensuring an enabling environment in the mining location and they impact the policy of Governments through their support or protests.

Foreign financiers and home countries of the oil companies like the United States, the European Union, Japan and China are potentially important enablers of LC in developing countries. By supporting the LC aspirations of developing countries they provide an important negotiating strength against the powerful MNC producers. Powerful multi-lateral agencies like the World Bank and IMF are increasingly playing a neutral role and supporting the LC aspirations of

developing countries. Historically, foreign companies' involvement in developing countries has been motivated by a desire to exploit natural resources and abundant labor pools (Hansen, 


\section{Richard A Owusu, Terje I Vaaland \\ Achieving Local Content in Extractive Industries of African Countries}

Pedersen \& Petersen, 2009). Finding the right mix between incentives and regulation is one important task for the industrial regulator in order to foster local participation through foreign companies (Kasuga, 1999). Based on experiences from the development of Brazilian oil industry, specific government imposed strategies are necessary to facilitate technology transfer from the MNC and to attract R\&D activities into the industry (Hernandez-Perez, 2011).

In order to meet reluctance from MNCs to actively promote indigenous companies, Moser (2001) emphasizes the importance of external institutional pressures (i.e. institutional capabilities) principally in the form of legislation for MNCs contribution to sustainable development of developing countries. Recently, the Government of the Federal Republic of Nigeria has passed a LC law to ensure expanded LC (Federal Government of Nigeria, 2010: Atsegbua, 2012). Initially, the multi-national oil producers opposed the effort but later supported it with promises of training, funding and technological transfer to local suppliers.

\subsubsection{Institutional Challenges}

Ability of institutions to carry out their tasks can be related to their powers and accountability, political stability, government effectiveness, regulatory quality, rule of law and control of corruption (Klueh et Al., 2009). Fattouh \& Darbouche (2010) identify significant variations in performances and capabilities among NOCs in developing countries. For example, Boscheck (2007) claims that the Nigerian National Oil Company (NNPC) has exemplified poor governance, high levels of corruption, and inefficiencies in important tasks such as record keeping and collection of equity oil since its establishment in the early seventies. In some countries, (e.g. Nigeria and Ghana) the economic conditions for local industry such as; tariffs and exchange policies do not support local industrial development (Ilori et al., 2002). One example is when duty free industrial zones favor imported finished goods, while raw materials for local industrial production are heavily taxed (Ilori et al., 2002). In many developing countries, the legal system and their institutions suffer from a variety of challenges. The legal system in Nigeria, for example, is claimed to have lacked accountability and suffered from corruption, which in turn inhibited investments (Nwosu et al., 2006). In Frynas' (2001) study of the Nigerian court system, he argues that access to courts is a key test of the quality of a legal system, and identifies obstacles like the potential plaintiffs' lack of financial resources, long delays in the disposal of cases, and intimidation by public bodies. Deficient public infrastructure can always discourage investment and lead to low LC (Nwosu et al., 2006). In Nigeria, unstable electricity supply has forced virtually all large industrial companies to invest in backup generators with a view to avoid temporary shutdowns (Ilori et al., 2002). The situation is similar in many emerging countries like Uganda, Ghana, India and Pakistan. Many observers have criticized foreign Governments, particularly China, for pushing the economic interests of their companies to the detriment of the host economy. China has negotiated many oil and mineral contracts in African countries that are accused of not benefitting the local economy (Ramburuth, Buatsi and Owusu, 2010). In Angola and Zambia, for example, Chinese companies have used large numbers of Chinese workers and suppliers for their projects. This reduces the roles of local contractors to low technology land clearing and transportation tasks.

\subsubsection{Inter-firm Enablers and Challenges}

Inter-firm enablers involve the indigenous company or contractor/supplier, defined as (i) registered in the host country with a 60-100\% local shareholding, (ii) possesses appropriate expertise, and financial viability, and (iii) has proven to be a contributor to the economic growth in its area of operation (Nwosu et al., 2006). In this definition, we exclude deliberate joint ventures between a foreign company and local interests that are established for the purpose of matching local content requirements without real value creation for the local economy. The host country firms in our context include all commercial suppliers that are directly or indirectly involved in the various levels of value creation and position in the supply chain within the extraction industry. Indigenous companies in developing countries appear to be breaking into a wide range of activities but in low technology and labor intensive areas primarily (Vaaland et al, 2012). Local content aims at improving local contribution in more advanced areas of technology 


\section{Richard A Owusu, Terje I Vaaland \\ Achieving Local Content in Extractive Industries of African Countries}

transfer, development and adoption. The development of indigenous suppliers particularly in technology intensive areas is hampered by the fact that they are SMEs; and are poorly linked to natural resource-based industries (Torres-Fuchslocher, 2010) and R\&D / university sector (Ojewale et al., 2001). Local content can be enhanced not just by foreign MNCs' willingness to transfer competence and effective industrial regulation but also by proactive indigenous companies willing to improve their competitiveness within products and delivery processes. One is to improve the competence and resource bases by mergers or acquisitions with a view to form larger and more powerful companies and also to develop various types of inter-firm linkages as a means to overcome most of the inhibitions preventing increased local content (Hansen et al, 2009). Another option is to increase the business-to- business interaction through forms of agglomerations in similar geographical areas (Silvestre \& Dalcol, 2009), and where stable platform for inter-firm cooperation and relation-based governance can be established (Biggs \& Shah, 2006).

\subsubsection{Foreign Multinational Company Enablers and Challenges}

Foreign multinational companies (MNCs) control mining and oil drilling in most African countries. Chinese companies are new entrants. For example, 95\% of the oil produced in Africa's largest petro-state Nigeria, is generated by five multinationals; Shell, Exxon, Chevron, Total and Agip (Frynas \& Paulo, 2006). Smaller MNCs like Tullow Oil and Kosmos Energy are dominating new exploration and production in, for example, Ghana and Uganda. The oil and gas related MNCs possess superior technical and economic capabilities, and represent an important potential source of competence and resources transfer to host countries. These are done through both physical investments, implementation of more effective managerial practices and transfer of best practice technologies (Silvestre \& Dalcol, 2009). Transfer of knowledge is not only restricted to transfer of technologies, but all types of specific support relevant for removing bottlenecks for a potential supplier in order to achieve the required performance level. The MNCs are therefore potentially important channels through which world-class knowledge can flow into natural resource industries and stimulate innovation in other local businesses (ibid). The extent of technological and managerial spillover from MNCs to indigenous companies and knowledge sector can be questioned. Some studies claim that the relationship between the MNCs and host developing countries suffer from low technological spillovers, especially the failure to develop dynamic local entrepreneurship in knowledge intensive areas (Ivarsson \& Alvstam, 2009). Others claim that attitudes among major foreign oil companies are impediments leading to low local participation (Nwosu et al., 2006; and Almeida \& Fernandes (2008), whereas others (e.g. Jordaan, 2011) scrutinize the formation of the supporting linkages from the MNEs to the local SMEs.

\subsubsection{Research and Educational Enablers and Challenges}

In this group, we find many types of state and private knowledge institutions established with the purpose of creating and diffusing scientific, managerial and technological knowledge. The institutions include research institutions, universities, polytechnics, and vocational schools. R\&D institutions have an important role in both creating and transforming foreign accessed knowledge into industrial applications. Development of technology intensive suppliers is assumed to have positive impacts on the industrialization process and economic development of natural resource-based industries (Torres-Fuchslocher, 2010). They are key energizers to industrialization and economic expansion in developing countries, mostly in fast growing oil producing countries (Mohamed et al., 2010). A main challenge is the incapacity of educational and research institutions. However, inadequate public funding and ineffective support for research and dissemination of knowledge from the private sector reduce their capability as a vehicle for upgrading indigenous companies. According to Britz et al., (2006), an oil producing country like Nigeria has only capacity to accommodate $12 \%$ of qualified candidates for higher education. Many R\&D institutions are inadequately staffed and poorly funded (Ilori et al., 2002), The low capacity leads to lack of high-quality entrepreneurial skills and relevant technical expertise (Nwosu et al., 2006). 


\section{Richard A Owusu, Terje I Vaaland \\ Achieving Local Content in Extractive Industries of African Countries}

\subsubsection{Financial Enablers and Challenges}

Financial institutions include banks and all types of capital providers in the host country. Other providers of financial capabilities include public funding institutions such as the Local Content Developing Fund in Nigeria. Their tasks include providing capital to indigenous companies for funding investments and providing operating credit lines for projects based on sound risk assessments. As suppliers have to pre-fund their work, emerging companies in developing countries are heavily dependent on funding. Many indigenous companies claim absence of adequate and appropriate financing (Nwosu et al., 2006). According to Ilori et al. (2002), the usually high cost of production in Nigeria is traceable to high exchange rates and lending rates, inadequate working capital and lack of investment funds to replace/refurbish worn-out machineries.

\section{Discussion}

An important enabler of local content is the capabilities provided by public institutions because they have the power to impose local content laws, financial and operational regulations, and requirements to foreign operators as well as providing incentives for the local industry. As Table 1 shows, the effect of institutional enablers is, however, dependent on other enablers. These include other local and international institutions, MNCs, local firms, financial institutions, research and educational institutions. For example, the current indigenous mining and oil \& gas related supplier industry often lack capabilities to provide high technology deliveries within recognized quality standards. One way to mitigate this problem is said to be to combine foreign participation in resource exploitation with technology transfer to the host country. The public institutions and regulators could therefore apply their powers in forcing and/or motivating foreign operators to sustain technology and competence transfer with the aim of developing the indigenous companies. Principals and suppliers need a dependable legal system. Without wellfunctioning legal systems, opposing parties would be forced to apply personal trust as the only governance mechanism, which in the final analysis is unrealistic in any business society. Two issues that arise from this in the African context are (i), how can the laws relating to business be aligned with international law and at the same time meet the national interests; and (ii) how can corruption be reduced effectively from the courts and through the law enforcement agencies? Another enabler focuses on the financial capabilities, where access to capital at competitive interest rates is assumed to be the major issue to be solved. The indigenous companies require operational credit lines and project funding, which may be difficult in many African countries. One factor is that of low lending power of the financial institutions. The other is the smallness of the institutions of both the lenders and borrowers alike. Also business professionalism has further implications on the ability of companies to develop products and services and make managerial decision making and delivery processes that are necessary for local content to prosper. Nonetheless, the funding issue also raises two pertinent questions for the country. The first is whether the lenders and borrowers alike would wish to restructure with a view to enhance their business powers and capabilities in the face of the need for larger business units. The other is the ability to achieve a legal system capable of providing efficient protection from fraud and defaulting business practices. The level of education and training, technology development and diffusion are among the main constraints to building a competitive local industry. Some of these relate to how the institutions are managed, funded and organized. Some others focus on how competence is accessed and applied in the companies. The local R\&D institutions and universities (and indeed, other technical and poly-technical schools of relevance) face the challenge to develop relationships with the MNCs and local industry in order to improve curriculum and industrial relevance and also to build up training facilities that are based on modern technological equipment and tools. Beyond low value catering, transportation and safety services, tight relationships between foreign companies, indigenous companies and the knowledge sector are very crucial for building capabilities that are necessary for making local content a reality.). The concerns around these are (i) how the universities and R\&D institutions can be sufficiently prepared financially and capacity wise to be able to adopt and distribute technology transferred from MNEs to local industry; and (ii) whether the schools and 
Richard A Owusu, Terje I Vaaland

Achieving Local Content in Extractive Industries of African Countries

universities are organized and managed sufficiently to meet industry requirements for their primary and further education.

\begin{tabular}{|c|c|c|}
\hline Actors & $\begin{array}{l}\text { Required capabilities / } \\
\text { Enabling aspects }\end{array}$ & $\begin{array}{l}\text { Challenges / Constraints related to } \\
\text { other actors }\end{array}$ \\
\hline $\begin{array}{l}\text { Institutional } \\
\text { (Local } \\
\text { political, } \\
\text { parastatal } \\
\text { and } \\
\text { internationa } \\
\text { I } \\
\text { institutions) }\end{array}$ & $\begin{array}{l}\text { Dependable authorities, } \\
\text { functional infrastructure, a } \\
\text { sound legal system; } \\
\text { industrial policy fostering } \\
\text { local content; foreign } \\
\text { institutional support }\end{array}$ & $\begin{array}{l}\text { Corruption hampering institutional } \\
\text { governance (all enablers); weak contribution } \\
\text { to institutional building (external institutional } \\
\text { enablers); weak generation and diffusion of } \\
\text { know-how (research \& educational } \\
\text { enablers); weak industrial links between } \\
\text { MNE and indigenous companies (weak intra- } \\
\text { firm enablers); } \\
\text { weak capacities and negative positions of } \\
\text { NGOs and local institutions }\end{array}$ \\
\hline $\begin{array}{l}\text { Foreign } \\
\text { Multination } \\
\text { al } \\
\text { corporation } \\
\text { (MNC) }\end{array}$ & $\begin{array}{lr}\text { Transfer of technology and } \\
\text { know-how. } \\
\text { backward } \\
\text { linkages to indigenous } \\
\text { companies }\end{array}$ & $\begin{array}{l}\text { Weak local industrial base and small scale } \\
\text { businesses (inter-firm enablers); weak legal } \\
\text { protection and infrastructure (institutional. } \\
\text { enablers); weak local institutions } \\
\text { (institutional enablers); weak foreign } \\
\text { institutions (institutional enablers) }\end{array}$ \\
\hline Inter-firm & 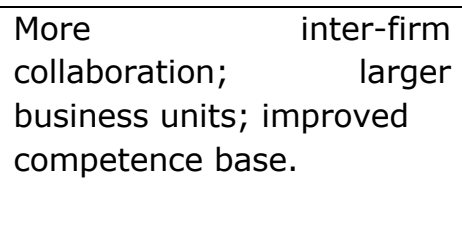 & $\begin{array}{l}\text { Lack of trust in legal system (institutional } \\
\text { enablers); weak financial system (financial } \\
\text { enablers), weak } \\
\text { access to R\&D (educational \& research } \\
\text { enablers) }\end{array}$ \\
\hline $\begin{array}{l}\text { Research \& } \\
\text { educational }\end{array}$ & $\begin{array}{l}\text { Transfer of know-how to } \\
\text { indigenous companies; high } \\
\text { R\&D and educational } \\
\text { output. }\end{array}$ & $\begin{array}{l}\text { Low ability to assimilate technological } \\
\text { developments in companies (inter-firm } \\
\text { enablers); weak relationships between } \\
\text { relevant actors (inter-firm and institutional } \\
\text { enablers); low involvement from MNEs } \\
\text { (external development enablers); Lack of } \\
\text { funding (institutional } \\
\text { enablers) }\end{array}$ \\
\hline Financial & $\begin{array}{l}\text { Credit access and } \\
\text { competitive interest rates. }\end{array}$ & $\begin{array}{l}\text { Weak economy hampering banking and } \\
\text { financial system (institutional enablers); } \\
\text { weak legal system hampering financial } \\
\text { relationships (institutional enablers.); weak } \\
\text { payback attitudes and low business } \\
\text { professionalism (inter-firm enablers). }\end{array}$ \\
\hline
\end{tabular}

Table 1: Enablers and of local content and their inter-related challenges

Another enabler is summarized in the external development capabilities in which the willingness and ability of foreign multinationals to provide managerial and technological competence to indigenous companies are essential. The consequences of weak vertical (backward) links represent a major constraint to local content. While transfer of competence from foreign operators can improve the capabilities of the local supplier industry, it does not necessarily imply that contracts can be awarded. The important questions that arise from these are (i) Whether the foreign companies (often powerful MNCs) are actually willing to develop small local suppliers with limited competence and capacities with a view to enter global supply chains without strong incentives from governmental bodies; and (ii) whether the MNCs are prepared to help develop local companies in a way which will reduce their (MNCs) power.

The final group of enablers focuses on inter-firm capabilities. It relates to how indigenous companies can develop their resource base and apply this to the production and delivery 


\section{Richard A Owusu, Terje I Vaaland \\ Achieving Local Content in Extractive Industries of African Countries}

processes. Taking into consideration the small and informal nature of most businesses in African countries compared to the large multinationals and foreign suppliers, weaknesses in horizontal intra-industry collaboration among local suppliers might prevent active participation of the local industry in the country's extractive industries. Table 1 above summarizes the discussion and emphasizes that local content should never be an isolated question about how individual public and private actors approach the issue. Rather, it should be approached with the understanding of the interdependencies, challenges and opportunities in combining the capabilities of the five groups of actors.

The challenges / constraints in Table 1 show how the challenges of achieving LC are interrelated. Just as the capability of each enabler is important, the cooperation of each enabler in overcoming their own constraints and helping to overcome inter-related constraints is critical for the process. Whereas the main constraints have previously been blamed by different researchers on specific actors - e.g. corruption and lack of capabilities in emerging countries like Nigeria, or capitalist greed and refusal to support local development by MNCs like Shell Oil, the framework in Table 1 confirms that failure is likely to emanate from several actors. In other words, each single actor can easily sabotage the achievement of LC by not dealing with its constraints. Thus far, LC has been poorly achieved in African countries. To improve on that we suggest the concept of mutual constraint mitigation which requires that the actors all commit to removing constraints in their organizations as well as those that are embedded in the links between them. This suggests the actors will actively strategize to work towards achieving LC from the point of view of their organizations as well as the necessary mutual activities.

\section{Conclusion}

This paper discussed an important international business issue that is only sparsely addressed in research. We answered the questions: how can increased LC be achieved in the extractive industries of developing countries? What are the enablers and challenges? We approached our aims by a literature review which we contextualized in a developing country perspective by illustrating it with primary and secondary data.

We propose a managerial and behavioural perspective and an integrative approach in order to understand inter-relationships, interactions, roles, and coordination among the actors which our research shows to be the critical issues for achieving LC. According to the model in Table 1 , five groups of enablers and challenges exist for achieving LC in developing and emerging countries. Their capabilities should be used to establish the required enabling environment as well as mitigate constraints.

A new study should investigate the relative importance of the five capabilities in different natural resource-based industries in different developing countries. Many new oil and mineral producers in Africa and other developing countries provide a live laboratory for studying the progress of LCs. Researchers should design longitudinal studies to follow the progress of LC and also use quantitative methods for cross-sectional studies.

\section{References}

- Almeida, R., Fernandes, A.M., (2008). Openness and technological innovations in developing countries: Evidences from firm-level surveys. Journal of Development Studies. CrossRef

- Atsegbua, L.A. (2012). The Nigerian Oil and Gas Industry Content Development Act 2010: an examination of its regulatory framework, OPEC Energy Review. 
- Biggs, T., Shah, M.K., (2006). African SMES, networks, and manufacturing performance. CrossRef

- Journal of Banking and Finance. (2006). CrossRef

- Boscheck, R., (2007). The governance of oil supply: an institutional perspective on NOC control and the questions it poses. International Journal of Energy Sector Management. CrossRef

- Fattouh, B., Darbouche, H., (2010). North African oil and foreign investment in changing market conditions. Energy Policy. CrossRef

- Federal Government of Nigeria (2010). Nigerian Oil and Gas Industry Content Development Law 2010.

- Frynas, J.G., (2001). Problems of access to courts in Nigeria: results of a survey of legal practitioners. Social \& Legal Studies. CrossRef

- Frynas, J.G., Paulo, M., (2007). A new scramble for African oil? Historical, political, and Business perspectives. African Affairs. CrossRef

- Giroud, A. (2007). MNEs vertical linkages: The experience of Vietnam after Malaysia. International Business Review. CrossRef

- Hansen, M.W., Pedersen, T., Petersen, B., 2009. MNC strategies and linkage effects in developing countries. Journal of World Business. CrossRef

- Hernandez-Perez, A., (2011). Economics of oil regulation and the Brazilian reform: Some issues. Energy Policy. CrossRef

- Heum, P., (2008). Local content development - experiences from oil and gas activities in Norway. Institute for Research in Economics and Business Administration, Bergen, Norway.

- Ivarsson, I., Alvstam, C.G., (2009). Learning from foreign TNCs: a study of technological upgrading by local suppliers to $A B$ Volvo in Asia and Latin America. International Journal of Technology Management. CrossRef

- Jordaan, J.A., (2011). FDI, Local Sourcing, and Supportive Linkages with Domestic Suppliers: The Case of Monterey, Mexico. World Development. CrossRef

- Klueh, U.H., Pastor, G., Segura, A., 2009. Policies to improve the local impact from hydrocarbon extraction: Observations on West Africa and possible les sons for Central Asia. Energy Policy. CrossRef

- Kwon, C-W., Chun, B.G., (2009). Local content requirements under vertical technology diffusion. Review of Development Economics. CrossRef

- Mohamed, A.S., Sapuan, S.M., Megat, A., Hamouda, A.M.S., Hang Tuah Bin Baharudin, B.T., (2010). Modeling technology transfer for petroleum industry in Libya: An overview. Scientific Research and Essay.

- Moser, T., (2001). MNCs and sustainable business practice: The case of the Columbian and Peruvian petroleum industries. World Development. CrossRef

- Nwosu, H.U., Nwachukwu, I.N., Ogaji, S.O.T., Probert, S.D., (2006). Local involvement in harnessing crude oil and natural gas in Nigeria. Applied Energy. CrossRef

- Ojewale, B.A., Ilori, M.O., Oyebisi, T.O., Akinwumi, I.O., (2001). Industry-academic relation: Utilization of idle capacities in polytechnics, universities and research organizations by entrepreneurs in Nigeria. Technovation. CrossRef

- Pursell, G. (2001). The Australian experience with local content programs in the auto industry - Some lessons for India and other developing countries. Journal of World Trade. CrossRef

- Ramburuth, P., Buatsi, S. and Owusu, R. (2010). The Chinese Dragon Engages Africa: Opportunities and Challenges. In: Wang Y. and Ramburuth P. (ed.) Thirty Years of China's Economic Reform: Institutions, Management Organizations and Foreign Investment.

- Silvestre, B.d.S.; Dalcol, P.R.T., (2009). Geographical proximity and innovation: Evidences from the Campos basin oil \& gas industrial agglomeration-Brazil. Technovation. CrossRef 


\section{Richard A Owusu, Terje I Vaaland}

Achieving Local Content in Extractive Industries of African Countries

- Takechi, K., Kiyono, K., (2003). Local content protection: specific-factor model for intermediate goods production and market segmentation. Japan and the World Economy. CrossRef

- Torres-Fuchslocher, C., (2010). Understanding the development of technology-intensive suppliers in resource-based developing economies. Research Policy. CrossRef

- Twerefou, D.K., Nimo, M.K., (2005).The impact of macroeconomic risk on asset prices in Ghana, African Development Review-Revue Africaine de Developpement. CrossRef

- Vaaland, Terje, Soneye, Alabi \& Owusu, Richard, 2012: Local content and struggling suppliers: A network analysis of the Nigerian oil and gas industry, African Journal of Business Management. CrossRef

- Veloso, F.M., 2006. Understanding Local Content Decisions: Economic Analysis and an application to the Automotive Industry. Journal of Regional Science. CrossRef 